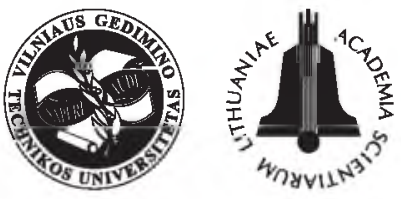

TRANSPORT

2010

25(4): 442-447

\title{
DEPENDENCE OF EVAPORATION LOSSES ON PETROL QUALITY
}

\author{
Larisa Chernyak ${ }^{1}$, Sergey Boychenko ${ }^{2}$, Ludmila Fedorovich ${ }^{3}$, \\ Valentina Novikova $^{4}$, Rasa Prentkovskiené ${ }^{5}$, Saugirdas Pukalskas ${ }^{6}$ \\ 1, 2, 3, 4 Ukrainian Research and Educational Center of Chemmtology and Certification of Fuels, \\ Lubricants and Technical Liquids, National Aviation University, \\ Kosmonavta Komarova ave 1, office 1.402, $03680 \mathrm{Kiev}$, Ukraine \\ ${ }^{5}$ Dept of Transport Technological Equipment, Vilnius Gediminas Technical University, \\ Plytinés g. 27, LT-10105 Vilnius, Lithuania \\ ${ }^{6}$ Dept of Automobile Transport, Vilnius Gediminas Technical University, \\ J. Basanavičiaus g. 28, LT-03224 Vilnius, Lithuania \\ E-mails: ${ }^{1}$ larikch@bigmir.net; ${ }^{2}, 3,4$ chemmotology@ukr.net; \\ ${ }^{5}$ rasa@vgtu.lt; ${ }^{6}$ saugirdas.pukalskas@vgtu.lt
}

Received 14 March 2009; accepted 15 November 2010

\begin{abstract}
The paper deals with the interrelation between evaporation losses and automobile petrol quality and presents the results of research on modern petrol. It has been established that evaporation leads to an increase in heavy hydrocarbon concentration in petrol composition adversely affecting its quality and operational properties at the excess of permissible concentration.
\end{abstract}

Keywords: losses, evaporation, automobile petrol, quality.

\section{Introduction}

In general, the losses of petroleum are divided into quantitative (in case of leakage or emission), quantitative-qualitative (in case of quantitative losses and a simultaneous deterioration of petroleum quality) and qualitative (deterioration of petrol quality without physical bulk losses) (Бойченко 2001).

The reduction of petroleum losses is one of the major ways of resource economy. If the stocks of petroleum are limited and its extraction requires increasing efforts, it is natural to pay more attention to saving the readymade product.

Irrespective of losses, liquid hydrocarbons finally escape in the atmosphere and have a negative impact on the environment and human health in particular (Karakitsios et al. 2007). The emissions of high concentration of hydrocarbons cause an increase in respiratory diseases, functional changes in the central nervous system etc.

Exposure to volatile organic compounds (VOC) can bring a variety of harmful health effects, including asthma, headaches and, in some cases, an increased risk of cancer (Terrés et al. 2010).

Therefore, the European Commission (EC) puts forward a proposal to make Stage II petrol vapour recovery systems mandatory for certain types of service station (Stage II Petrol... 2005). The EC suggests relaxing the vapour pressure requirements of petrol via its revised directive on petrol and diesel quality. The issued directive would require the installation of Stage II petrol vapour recovery equipment at all new stations with more than 500-square meter throughput of petrol a year and at all new stations under permanent living quarters of working areas.

Air pollution has assumed gigantic proportion killing almost half a million Asians every year. Urban pollution mainly comprises of emissions from buses, trucks, motorcycle and other forms of motorized transport along with its supporting activities. As Asian cities continue to expand, the number of vehicles has risen resulting in greater pollution. Fugitive emissions from the retail distribution centre in the urban area constitute a major source. Petrol vapours escape during refuelling adding pollutants like benzene, toluene, ethyl benzene and xylene to ambient air (Srivastava et al. 2005).

VOCs are important air pollutants in the urban atmosphere. Some of the VOCs are toxic, potentially carcinogenic and mutagenic at concentrations levels found in the urban environment (Edgerton et al. 1989). Exposure to VOCs is of concern as it may result in significant risk to human health. Atmospheric reactions of VOCs lead to 
secondary pollutants, which is turn cause the deterioration of air quality and damage to Corps and vegetation. VOCs are emitted from a number of sources, including urban and industrial activities as well as natural sources.

The distribution units of oil products are among the main sources of VOC emissions released in transportation, loading, storing these products and cleaning oil tanks. VOC emissions not only increase the pollution of the atmosphere but also lead to great losses of oil products and specifically petrol (Sudintas 2008).

The greatest share of all kinds of losses during transportation, storage and use falls to evaporation. Such losses are very typical of hydrocarbons which easily evaporate (Хизгилов 1965). The specific losses of hydrocarbons due to evaporation at refineries in the different parts of the world make up 1.1-1.5 kg per 1 tone of petroleum (Зеркалов 1990). In 1998, the emissions of hydrocarbons in the processes of petroleum production in the Russian Federation comprised 1168 thousand tones. Besides, plenty of petroleum is lost during usage and as a result of wrong conservation. According to some information, refuelling stations of the Russian Federation release into the atmosphere more than 140 thousand tons of hydrocarbon fumes a year, whereas refuelling stations in Germany give 145 thousand and England - 120 thousand tons a year (Цегельский $u \partial p$. 2001).

\section{Works Related to the Considered Problem}

Fuel evaporation has a negative impact on fuel quality which also influences the operating characteristics and performance of vehicle engines. Another important factor is that fuel evaporation negatively affects the environment and people's health.

A brief survey of the revised scientific papers is presented below.

Scientific research by Sturm et al. (1996) offers an overview of methods that may realistically be used depending on specific needs and the accuracy required to describe the emission behaviour of road transport. These include emission computation methods based on real driving behaviour, the methods based on road type classification to facilitate emission inventory development and mileage related emission balances.

A review paper by Brice and Derwent (1978) contains a survey of man's activities which give rise to hydrocarbon emissions in the United Kingdom. The main contributions to total emissions appear to come from motor vehicles, industrial non-combustion sources and solvent usage.

The mass and heat transfer processes occurring during the evaporation of liquid hydrocarbon spills on land and water are described by Mackay and Matsugu (1973) predicting the equations developed to enable liquid temperature and evaporation rate. Experiments on the evaporation of cumene, water and gasoline are described. Evaporation mass transfer coefficient correlated referring to wind-speed, liquid pool size and the vapour phase Schmidt Number. A good agreement is obtained between experimental and computed cumene temperature and evaporation rates.
The main environmental problem of emitting VOCs from oil terminals was analyzed by Paulauskiene et al. (2007) who proposed VOCs concentration VOCs dispersion modelling results. A discreet area containing three types of cells (totally blocked - buildings, partly blocked - forest, not blocked - other area) was identified. Research on VOCs concentration in oil terminal was conducted in the characterized spots of main pollutant concentration (storage tank parks of light and heavy oil products and railway trestles). The purpose of research is to represent the results of VOCs dispersion in the near earth atmospheric boundary layer following the mathematical model.

Research by (Lashkova et al. 2008) considers the evaporation of VOCs at a port oil terminal. The obtained experimental data and metrological conditions are examined (air temperature and humidity, atmospheric pressure, wind force and direction) on the basis of transfer operations and the types of oil products. The experimental results are compared with monitoring values indicating ranges in air humidity, wind force, and atmospheric pressure and having no impact on VOC concentration in the environment.

The problem of VOC emission from ISC Klaipedos nafta oil terminals is discussed in research by Lashkova et al. (2007). Short-term analyses were performed to determine the dependence of VOC on wind speed, environmental humidity and atmospheric pressure at minimal ambient air temperature variations $\left(1-3^{\circ} \mathrm{C}\right) .10$-day VOC concentration analyses were performed using gas chromatography. Complex analysis of experimental investigation and meteorological conditions (air temperature, environmental humidity, atmospheric pressure, wind speed and direction) was carried out considering the types of loading operations and oil products at the oil terminal. Dependencies between VOC concentration and separate meteorological parameters were determined.

A study carried out by Ye et al. (1998) reports the identification and quantification of 1,3-butadiene in petrol and evaporative emissions from Australian light-duty passenger vehicles. The mass fraction of 1,3-butadiene in each of the different grades of any brand of Australian petrol was found to be relatively constant for a given marketing area. However, mass fractions vary significantly between different brands (or refineries). The measurements of the evaporative emissions of 1,3-butadiene from in-service motor vehicles were performed using standard Australian Design Rule 37/00 (ADR 37/00) and Sealed Housing Evaporative Determination (SHED) tests.

Pukalskas et al. (2009) carried out research related with the mixture of biobutanol and petrol for Otto engines. The expansion of production and the use of biofuels are determined by the legal acts of the European Commission and National legal acts encouraging such production and usage. It would be meaningful to use the mixtures of butanol and petrol in Otto engines. Fuel must be evaporated in the engine before combustion. Evaporation is an important problem when alcohol fuels 
are used and when the engine is ignited with cold air. The latent evaporation heat of butanol is twice smaller than that of ethanol, thus the start of the engine using butanol should be easier than that using ethanol or methanol. The standards of the mixture of ethanol and methanol with petrol exist in many countries, including the EU, USA and Brazil. The estimated equivalent butanol mixtures may be calculated according to the stoichiometric ratio of fuel-air for butanol, ethanol and petrol. The amount of ethanol in the most widely sellable mixture of ethanol and petrol varies from 5 to $10 \%$. In case of butanol, this amount may be higher by $60 \%$ than in the case of ethanol and may vary from 8 to $32 \%$. However, due to solubility, latent evaporation temperature and octane number as well as the amount of butanol in the mixtures with petrol may reach $25 \%$.

The influence of fuels or fuel additions evaporation in the combustion chamber of internal combustion engines was investigated in works by Labeckas and Slavinskas (2010), Raslavičius and Bazaras (2010), Matijošius and Sokolovskij (2009), Török (2009), Lebedevas et al. (2007, 2009, 2010), Yao et al. (2008), Saveljev (Савельев 2006), Mittelbach and Remschmidt (2004), Yoshimoto and Onodera (2002), Lyotko et al. (Льотко u дp. 2000), etc.

Apparently, fuel evaporation renders negative and positive influences depending on the investigated problem.

\section{Research}

Evaporation losses are usually considered from the quantitative point of view and the fact that poor-quality fuel causes negative changes in engine condition which is not always taken into account. Because of these losses, the boiling point and density of petrol raise and such important parameter of petrol quality as an octane number is reduced, which results in an increase in petrol consumption in engine operation and its malfunction. For example (Хизгилов 1965), the total evaporation losses of $1.2 \%$ at storing the parameters of its quality change in the following way: relative density increases by $0.002 \mathrm{~g} / \mathrm{cm}^{3}$, boiling point - by $3{ }^{\circ} \mathrm{C}$, boiling off point by $10 \%$ or $2{ }^{\circ} \mathrm{C}$, saturation pressure - by $20 \%$ and an octane number drops by 0.5 unit.

\section{Task Formulation}

The purpose of research was to define the interrelation between evaporation losses and petrol quality. The task was solved based on the analysis of funded literary materials and information concerning factors affecting petrol evaporation, and therefore a series of experiments were conducted to define the precise character of possible dependencies.

\section{Investigation on petrol quality}

The compliance of petrol quality with technical and economic requirements is defined by its operational properties. Apart from the most important physical and chemical properties (determined under laboratory conditions and used for an initial or control evaluation of oil quality in the places of production and application) the following operations (objective features of fuel showing up during the process of applying them in engine) are of the highest interest: detonation stability, vaporization, starting properties, acceleration ability, engine reception, stability, the index of steam fuse (Большаков 1987; Гайванович $u \partial p$. 2000).

The evaporability of petrol is characterized by saturation pressure and fractional composition. As the density of petrol vapour is higher than air density, evaporation takes place on the surface of petrol. Vapour is carried out from the surface due to diffusion: vapours formed over the surface of liquid finally reach saturation condition and then are widely distributed in the environment. The total speed of evaporation can be determined as either the intensity of the diffusion process or the speed of molecule evaporation from the surface layer of the liquid. Depending on the relation of these speeds, it is possible to distinguish two modes of evaporation: diffusive if its speed is limited by the speed of vapour diffusion in the environment and kinetic, provided that it is determined in the molecular and kinetic parameters of the liquid. In the latter case, a maximal speed of evaporation also depends on the temperature and properties of the evaporated liquid. In most cases, fuel evaporates as a result of diffusion from the surface (Абузова $u \partial p$. 1981; Гуреев, Азев 1996). Therefore, possibly, the greater is the diffusion factor, the faster this component will evaporate. The factors of individual hydrocarbon diffusion into the air are given in Table 1 (Дубовкин $и$ др. 1985; Викторов 1977).

Table 1. Factors of hydrocarbon diffusion into the air at $20^{\circ} \mathrm{C}$

\begin{tabular}{cc}
\hline Hydrocarbons & $\begin{array}{c}\text { Diffusion factor } \\
D \times 10^{6} \text { at } 0.1 \mathrm{~Pa}, \mathrm{~m}^{2} / \mathrm{sec}\end{array}$ \\
\hline Ethanol & 11.89 \\
\hline Benzene & 8.95 \\
\hline Toluene & 8.109 \\
\hline Cyclohexane & 7.45 \\
\hline Hexane & 7.23 \\
\hline Heptane & 6.65 \\
\hline Octane & 6.091 \\
\hline Decane & 5.61 \\
\hline Nonane & 5.48 \\
\hline
\end{tabular}

The table shows that oxygen components have the highest diffusion, and therefore oxygen components will evaporate from petrol faster than others. As soon as similar components are included in petrol composition to its octane number to improve starting properties, such operational parameters as the octane number and fractional composition will change first after the process of evaporation.

The given research was conducted using the petrol brand A-92 (according to TY Y 00149943.501-98). The research object was to develop the model of petrol evap- 
oration involving the above mentioned important operational parameters. At the end of evaporation, a change in the values of these parameters was investigated. Thus, for the first time, research on the composition of a petrol group was carried out considering this evaporation model.

The hydrocarbon structure of petrol samples before evaporation was analysed applying the method of chromatography. The conducted research disclosed that $42.3 \%$ of petrol evaporated. The dynamics of evaporation is indicated in Figure.

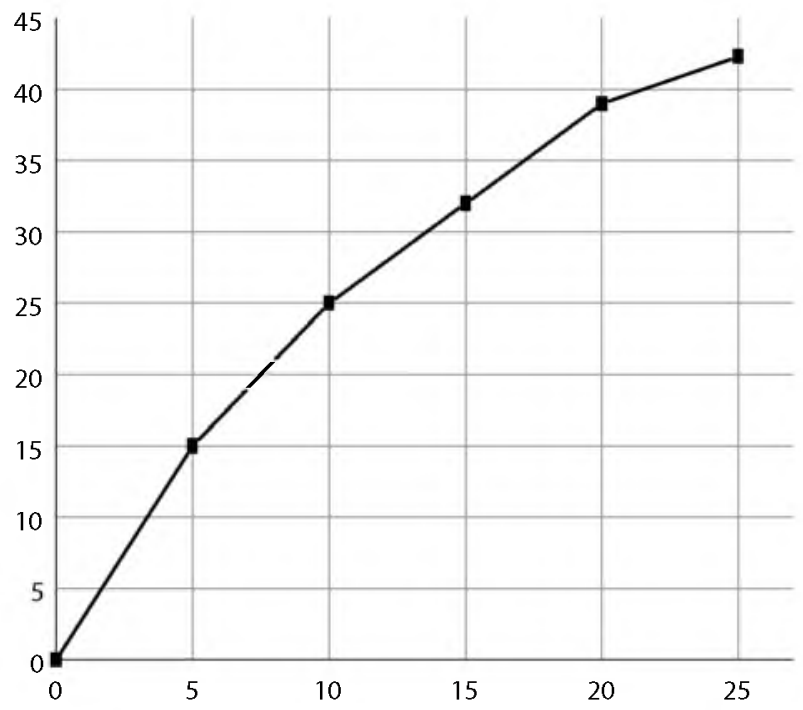

Fig. Dynamics of automobile petrol losses

Petrol samples were analyzed using chromatograph Crystal-2000 equipped with capillary column of $50 \mathrm{~mm}$ length and a section of $0.2 \mathrm{~mm}$ with polymethylsilicone as the liquid phase. The test lasted $70 \mathrm{~min}$. Information on changes in petrol composition as a result of experimental evaporation are submitted in Table 2.

At this investigation phase, a possible conclusion can be made that during evaporation, alkanes are first to evaporate and losing a part of atoms partially turn in cyclic alkanes and aromatic hydrocarbons. It was confirmed on the following investigation phase analyzing concentration changes in individual hydrocarbons.

Information concerning a change in the individual concentration of hydrocarbons due to evaporation is submitted in Table 3. Changes in fuel composition owing to evaporation are shown in the example of typical hydrocarbons representing different classes.

Table 3 shows research results that the lightest alkane components of fuel including propane, isobutane, butane, isopentane and pentane were completely evaporated.

The concentration of hexane decreased approximately 3 times. The concentration of the heaviest alkanes increased practically 1.5 times for undecane and dodecane.

Although cyclopentane concentration decreased, the only benzene concentration decreased 10 times
Table 2. Changes in petrol composition due to evaporation

\begin{tabular}{cccc}
\hline \multirow{2}{*}{$\begin{array}{c}\text { Class of } \\
\text { hydrocarbons }\end{array}$} & \multicolumn{2}{c}{ Content, \% } & Before \\
\cline { 2 - 3 } & $\begin{array}{c}\text { After } \\
\text { vaporization }\end{array}$ & Difference,\% \\
vaporization & \\
\hline Alkanes & 33.7 & 8.7 & -25.0 \\
\hline Cycloalkanes & 3.32 & 3.5 & 0.18 \\
\hline $\begin{array}{c}\text { Aromatic } \\
\text { hydrocarbons }\end{array}$ & 36.0 & 49.45 & 13.45 \\
\hline
\end{tabular}

Table 3. Changes in hydrocarbon concentration in petrol

\begin{tabular}{|c|c|c|c|}
\hline \multirow{2}{*}{ Hydrocarbon } & \multicolumn{2}{|c|}{ Content, \% } & \multirow{2}{*}{ Difference, \% } \\
\cline { 2 - 3 } & $\begin{array}{c}\text { Before } \\
\text { vaporization }\end{array}$ & $\begin{array}{c}\text { After } \\
\text { vaporization }\end{array}$ & \\
\hline \multicolumn{3}{|c|}{ Alkanes } \\
\hline Propane & 0.14867 & - & -0.14867 \\
\hline Isobhutane & 1.0655 & - & -1.0655 \\
\hline Bhutan & 1.9548 & - & -1.9548 \\
\hline Isopentane & 4.9377 & - & -4.9377 \\
\hline Pentane & 2.7987 & - & -2.7987 \\
\hline Hexane & 2.9976 & 0.93282 & -2.0647 \\
\hline Isooctane & 0.2182 & 0.19001 & -0.0282 \\
\hline Heptane & 1.7181 & 1.6764 & -0.0417 \\
\hline Octane & 0.64773 & 0.96463 & 0.3169 \\
\hline Nonane & 0.21108 & 0.40451 & 0.1934 \\
\hline Decane & 1.8078 & 0.17608 & -1.6317 \\
\hline Undecane & 0.16683 & 0.32385 & 0.1570 \\
\hline Dodecane & 0.29614 & 0.39614 & 0.1 \\
\hline \multicolumn{4}{|c|}{ Cycloalcane } \\
\hline Cyclopentane & 0.15566 & 0.1029 & -0.0526 \\
\hline Cyclohexane & 0.12985 & 1.5783 & 1.4484 \\
\hline \multirow{2}{|yyn}{} & Aromatic hydrocarbons \\
\hline Benzol & 2.9806 & 1.588 & -1.3926 \\
\hline Noluol & 10.548 & 13.049 & 2.501 \\
\hline O-xylene & 3.4376 & 5.7645 & 2.3269 \\
\hline
\end{tabular}

among all aromatic hydrocarbons because it has a greater diffusion factor of all aromatic hydrocarbons; the concentrations of other representatives increased considerably during evaporation.

An increase in the concentration of some hydrocarbons can be explained by the fact that within the process of evaporation, light hydrocarbons increase the concentration of heavier hydrocarbons owing to structural transformations under the influence of physical factors.

Besides, a change in physical and chemical parameters (Table 4) was investigated during research on changes in composition. 
The analysis of information provided in Table 4 has revealed that evaporation changes fuel composition as well as its important physical and chemical characteristics, such as fractional composition, flash temperature, an octane number, density and the total content of aromatic hydrocarbons.

Table 4. Changes in the qualitative characteristics of automobile petrol researching losses caused by evaporation

\begin{tabular}{|c|c|c|c|}
\hline \multirow[b]{2}{*}{ Parameters } & \multicolumn{2}{|c|}{ Actual value } & \multirow{2}{*}{$\begin{array}{c}\text { Absolute } \\
\text { difference, } \\
\%\end{array}$} \\
\hline & $\begin{array}{l}\text { Initial } \\
\text { petrol }\end{array}$ & $\begin{array}{c}\text { Petrol after } \\
\text { vaporization }\end{array}$ & \\
\hline $\begin{array}{l}\text { Fractional } \\
\text { composition: } \\
\text { - boiling point, }{ }^{\circ} \mathrm{C}\end{array}$ & 38 & 43 & 5 \\
\hline $\begin{array}{l}-10 \% \text { distilled at } \\
\text { temperature, }{ }^{\circ} \mathrm{C}\end{array}$ & 60 & 71 & 11 \\
\hline $\begin{array}{l}-50 \% \text { distilled at } \\
\text { temperature, }{ }^{\circ} \mathrm{C}\end{array}$ & 112 & 117 & 5 \\
\hline $\begin{array}{l}-90 \% \text { distilled at } \\
\text { temperature, }{ }^{\circ} \mathrm{C} \\
\text { - finishimg } \\
\text { temperature, }{ }^{\circ} \mathrm{C}\end{array}$ & $\begin{array}{r}166 \\
192 \\
\end{array}$ & $\begin{array}{r}168 \\
202 \\
\end{array}$ & $\begin{array}{l}2 \\
10 \\
\end{array}$ \\
\hline Flash point, ${ }^{\circ} \mathrm{C}$ & -29 & -22 & 7 \\
\hline $\begin{array}{l}\text { Surface tension, } \\
\mathrm{mN} / \mathrm{m}\end{array}$ & 22.9 & 23.5 & 0.6 \\
\hline $\begin{array}{l}\text { Saturated vapour } \\
\text { pressure, } \mathrm{kPa}\end{array}$ & 57.9 & 49 & 8.9 \\
\hline $\begin{array}{l}\text { Octane number by } \\
\text { motor method }\end{array}$ & 85 & 79 & 6 \\
\hline $\begin{array}{l}\text { Total content } \\
\text { of aromatic } \\
\text { hydrocarbons, } \%\end{array}$ & 360 & 49.45 & 13.45 \\
\hline $\begin{array}{l}\text { Mass part of } \\
\text { benzene, } \%\end{array}$ & 2.980 & 1.588 & 1.392 \\
\hline Density, $\mathrm{kg} / \mathrm{m}^{3}$ & 750 & 760 & 10 \\
\hline $\begin{array}{l}\text { Diffusion factor, } \\
10^{-6} \mathrm{~m}^{2} / \mathrm{s}\end{array}$ & 8.321 & 7.862 & 0.459 \\
\hline $\begin{array}{l}\text { Physical stability } \\
\text { (Budarov), \% }\end{array}$ & 1.074 & 1.03 & 0.044 \\
\hline
\end{tabular}

\section{Conclusions}

The evaporation of fuel results in an increase in the concentration of heavy hydrocarbons that might have a negative influence on petrol quality and operational properties if permissible concentration is exceeded.

Heavier petrol fractional composition results in the deterioration of starting properties, particularly at low temperatures, an increase in engine heating duration and its reception, reduction in engine work profitability and an increase in surface wear.

A decrease in an octane number results in fuel detonation combustion in the engine, which considerably reduces its resource.
Therefore, loss prevention from evaporation is important both for environmental safety and resource economy and for engine operation enhancement.

\section{References}

Brice, K. A.; Derwent, R. G. 1978. Emissions inventory for hydrocarbons in the United Kingdom, Atmospheric Environment 12(11): 2045-2054. doi:10.1016/0004-6981(78)90162-2

Edgerton, S. A.; Holdren, M. W.; Smith, D. L.; Shah, J. J. 1989. Inter-urban comparison of ambient volatile organic-compound concentrations in United-States cities, JAPCA - The Joumal of the Air \& Waste Management Association 39(5): $729-732$.

Karakitsios, S. P.; Delis, V. K.; Kassomenos, P. A.; Pilidis, G. A. 2007. Contribution to ambient benzene concentrations in the vicinity of petrol stations: Estimation of the associated health risk, Atmospheric Environment 41(9): 1889-1902. doi:10.1016/j.atmosenv.2006.10.052

Labeckas, G.; Slavinskas, S. 2010. The effect of ethanol, petrol and rapeseed oil blends on direct injection diesel engine performance and exhaust emissions, Transport 25(2): 116128. doi: 10.3846/transport.2010.15

Lashkova, T.; Zabukas, V.; Baltrènas, P.; Vaitiekūnas, P. 2007. Air pollution near a port oil terminal, Chemical and Petroleum Engineering 43(5-6): 358-361. doi:10.1007/s10556-007-0064-2

Laškova, T.; Zabukas, V.; Vaitiekūnas, P. 2007. Meteorologinių sąlygų ịtaka lakiujų organinių junginių sklaidai pažemés atmosferos sluoksnyje [Influence of meteorological conditions on volatile organic compound spread in the atmospheric boundary layer], Journal of Environmental Engineering and Landscape Management 15(3): 135-143 (in Lithuanian).

Lebedevas, S.; Lebedeva, G.; Makarevičienè, V.; Janulis, P.; Sendzikiené, E. 2009. Usage of fuel mixtures containing ethanol and rapeseed oil methyl esters in a diesel engine, Energy \& Fuels 23(1): 217-223. doi:10.1021/ef800512 Z

Lebedevas, S.; Lebedeva, G.; Makarevičiené, V.; Kazanceva, I. ; Kazancev, K. 2010. Analysis of the ecological parameters of the diesel engine powered with biodiesel fuel containing methyl esters from Camelina sativa oil, Transport 25(1): 22-28. doi: 10.3846/transport.2010.04

Lebedevas, S.; Vaicekauskas, A.; Suškov, P. 2007. Presumptions of effective operation of diesel engines running on RME biodiesel. Research on kinetics of combustion of RME biodiesel, Transport 22(2): 126-133.

Mackay, D.; Matsugu, R. S. 1973. Evaporation rates of liquid hydrocarbon spills on land and water, The Canadian Journal of Chemical Engineering 51(4): 434-439. doi: $10.1002 /$ cjce. 5450510407

Matijošius, J.; Sokolovskij, E. 2009. Research into the quality of fuels and their biocomponents, Transport 24(3): 212-217. doi: 10.3846/1648-4142.2009.24.212-217

Mittelbach, M.; Remschmidt, C. 2004. Biodiesel: a Comprehensive Handbook. Graz, Austria. 330 p.

Paulauskiené, T.; Vaitiekūnas, P.; Zabukas, V. 2008. Research and modelling transfer of volatile organic compounds (VOC), in 7 th International Conference Environmental Engineering, 22-23 May 2008,Vilnius, Lithuania, 442-447.

Pukalskas, S.; Bogdanovičius, Z.; Sendžikienè, E.; Makarevičienè, V.; Janulis, P. 2009. The mixture of biobutanol and petrol for Otto engines, Transport 24(4): 301-307. doi:10.3846/1648-4142.2009.24.301-307 
Raslavičius, L.; Bazaras, Ž. 2010. The possibility of increasing the quantity of oxygenates in fuel blends with no diesel engine modifications, Transport 25(1): 81-88. doi: $10.3846 /$ transport.2010.11

Srivastava, A.; Joseph, A. E.; More, A.; Patil, S. 2005. Emissions of VOCs at urban petrol retail distribution centres in India (Delhi and Mumbai), Environmental Monitoring and Assessment 109(1-3): 227-242. doi:10.1007/s10661-005-6292-z

Stage II Petrol Vapour Recovery - Final Report. 2005. Contract 070501/2004/379928/MAR/Cl. European Commission (DG Environment). Entec UK Limited. 199 p. Available from Internet: <http://ec.europa.eu/environment/air/pdf/ entec_report.pdf>.

Sturm, P. J.; Pucher, K.; Sudy, C.; Almbauer, R. A. 1996. Determination of traffic emissions - intercomparison of different calculation methods, Science of the Total Environment (189-190): 187-196. doi:10.1016/0048-9697(96)05209-6

Sudintas, A. R. 2008. VOC emissions when filling petrol tanks in Lithuanian terminals and their reduction, Environmental Research, Engineering and Management (2): 18-27.

Terrés, I. M. M.; Miñarro, M. D.; Ferradas, E. G.; Caracena, A. B.; Rico, J. B. 2010. Assessing the impact of petrol stations on their immediate surroundings, Journal of Environmental Management 91(12): 2754-2762. doi: $10.1016 / j$ j.jenvman.2010.08.009

Török, A. 2009. Theoretical estimation of the environmental impact of biofuel mixtures, Transport 24(1): 26-29. doi:10.3846/1648-4142.2009.24.26-29

Yao, C. D.; Zhang, Z. H.; Xu, Y. L.; Huang, Y. 2008. Experimental investigation of effects of bio-additives on fuel economy of the gasoline engine, Science in China Series E: Technological Sciences 51(8): 1177-1185. doi:10.1007/s11431-008-0170-1

Ye, Y.; Galbally, I. E.; Weeks, I. A.; Duffy, B. L.; Nelson, P. F. 1998. Evaporative emissions of 1,3-butadiene from petrolfuelled motor vehicles, Atmospheric Environment 32(1415): 2685-2692. doi:10.1016/S1352-2310(97)00379-8

Yoshimoto, Y.; Onodera, M. 2002. Performance of a Diesel engine fuelled by rapeseed oil blended with oxygenated organic compounds, SAE Technical Paper No 2002-01-2854.

Абузова, Ф. Ф.; Бронштейн, И. С.; Новоселов, В. Ф.; Ржавский, Е. Л.; Фокин, М. Н. 1981. Борвба с потерями нефти и нефтепродуктов при их транспортировке и хранении [Abuzova, F. F.; Bronshtein, I. S.; Novosiolov, V. F; Rzhavsky, E. L.; Fokin, M. N. Decrease in Petroleum Loses within Transportation and Storage]. Москва: Недра. 248 с. (in Russian).

Бойченко, С. В. 2001. Раціональне використання вуглеводневих палив: Монографія [Boychenko, S. V. Rational Use of Hydrocarbon Fuels. Monograph]. Київ: Національний авіаційний університет. 217 c. (in Ukrainian).

Большаков, Г. Ф. 1987. Физико-химические основы применения топлив и масел [Bolshakov, G. F. Physical and Chemical Properties of Fuels and Oils]. Новосибирск: Наука. 209 с. (in Russian).

Викторов, М. М. 1977. Методы вычисления физикохимических величин и прикладные расчёты [Viktorov, M. M. Applied Calculations and Methods for Determining Physical and Chemical Magnitude]. Москва: Химия. 360 c. (in Russian).

Гайванович, В. І.; Топільницький, П. І.; Палюх, В. М. 2000. Хіммотологія бензинів [Gaivanovich, V. I.; Topil- nyckyj, P. I.; Paliuh, V. M. Petrol Chemmotology]. Львів: Львівська політехніка. 157 с. (in Ukrainian).

Гуреев, А. А.; Азев, В. С. 1996. Автомобильные бензины. Свойства и применение [Gureev, A. A.; Azev, V. S. Types of Petrol: Properties and Usage]. Москва: Нефть и газ. 444 c. (in Russian).

Дубовкин, Н. Ф.; Маланичева, В. Г.; Массур, Ю. П.; Федоров, Е. П. 1985. Физико-химические и эксплуатационные свойства реактивных топлив: Справочник [Dubovkin, N. F.; Malanicheva, V. G.; Massur, Y. P.; Fiodorov, E. P. Physical and Chemical Properties of Jet Fuels. Reference Book]. Москва: Химия. 240 с. (in Russian).

Зеркалов, Д. В. 1990. Экономия нефтепродуктов [Zerkalov, D. V. The Economy of Petroleum Products]. Москва: Недра. 191 с. (in Russian).

Льотко, В.; Луканин, В. Н.; Хачиян, А. С. 2000. Применение альтернативных топлив в двигателях внутреннего сгорания [Lyotko, V.; Lukanin, V. N.; Khatchiyan, A. S. Usage of Alternative Fuels in Internal Combustion Engines]. Москва: МАДИ (ТУ). 310 с. (in Russian).

Савельев, Г. 2006. Применение альтернативных топлив в сельскохозяйственном секторе [Saveljev, G. Usage of Alternative Fuels in Agricultural Sector], Aльтернативные топлива [Alternative Fuels] 1(25): 64-70 (in Russian).

ТУ у 00149943.501-98. Бензини автомобільні з підвищеним кінцем кипіння [Technical Requirements. Petrol with Raised End Boiling Point] (in Ukrainian).

Хизгилов, И. Х. 1965. Сохранение качества нефтепродуктов при их mpaнсnорте и хранении [Hizgilov, I. Ch. Retention of Petroleum Product Quality within Transportation and Storage]. Москва: Недра. 192 с. (in Russian).

Цегельский, В. Г.; Ермаков, П. Н.; Спиридонов, В. С. 2001. Защита атмосферы от выбросов углеводородов из резервуаров для хранения и транспортирования нефти и нефтепродуктов [Cegelsky, V. G.; Yermakov, P. N.; Spiridonov, V. S. Atmosphere Protection Against Hydrocarbon Emissions from Tanks for Petroleum Storage and Transportation], Безопасность жизнеуеятельности [The Safety of Vital Activity] 3: 16-18 (in Russian). 